\title{
Youth Living Standards in Transforming Modern Society
}

\author{
Yana Chaplinskaya ${ }^{\mathrm{a} *}$ \\ * Corresponding author: Yana Chaplinskaya, yana16071992@ya.ru \\ ${ }^{a}$ Tomsk Polytechnic University, Lenina Street, Tomsk 634050, Russia, yana16071992@ya.ru, +7 (923) 4086118
}

\begin{abstract}
http://dx.doi.org/10.15405/epsbs.2017.01.18

This study covers the issue of modern society young generation life. The work focuses on the concept of a crowd and a possibility to keep the rising generation quality of life under control. The integrational processes of the Russian society implementation into the international community resulted in a gap between social transformation and their recognition. In multidimensional and fast developing modern society the youth faces a challenging existential issue. Modern young person life is inseparably connected with social life. The research is carried out by using the method of the comparative analysis supported by dialectic and competency-based approaches. From our point of view, a healthy Russian society task will be the leading one in the future country development. The focus will be turned to the person with his psychological and physiological health oriented to the human value in the society. Research goes within the solution of questions of social policy.
\end{abstract}

(C) 2017 Published by Future Academy www.FutureAcademy.org.uk

Keywords: Crowd, young generation, quality of life control.

\section{Introduction}

In multidimensional and fast developing modern society the youth faces a challenging existential issue. Now "the search" of oneself place in life is predominant. The integrational processes of the Russian society implementation into the international community resulted in a gap between social transformation and their recognition. It is important to understand that this process was started naturally. In other words, that was a self-constituent process in a global development context (Zakovorotnaya, 1999). Nowadays Russia is adopting and adjusting to the latest social transformation. 


\section{Methods}

The research is carried out by using the method of the comparative analysis supported by dialectic and competency-based approaches.

\section{Discussion of Research}

From our point of view, the Russian youth adaptive processes require special attention, which could be proved by the following statements.

1. Personal instability. A young person, pupil or a recent worker do not have a well-formed sustainable living position.

2. Non-family-membership. Here the concept of "alienation" is relevant. Phenomenology primarily defines it as "personal experiencing". The alien only becomes alien. Namely, "the secondary alienation" is viewed as a process of alienation formation from the supposed affiliation (Krieger, 2015). The current elder generation is children of a completely opposite society which leads to opposite younger generation values and views combination. That is why it is difficult for a young person to get a boost and support concerning personal life (Kvesko et al., 2015).

Modern young person life is inseparably connected with social life. Nowadays it is a well-known fact that the society holds one-dimensional man behavior. In works "Heroes and Crowd" and "Pathological Magic" a Russian scholar N.K. Michailovsky raises the question of imitativeness and its automatic subconscious form (Mikhaylovskiy, 1907). Today in the situation of social instability and inner imbalance in a crowd the Russian modern generation finds rescue in implication in the crowd and imitation of its behavior. To be a part of a crowd means to be released from responsibility to make a choice and to have an opportunity to get some place for oneself (Kachalov et. al., 2015).

This results in "a man of the crowd" lifestyle. It is a kind of unreflecting existence that holds a range of consequences. External consequences are geopolitical and ecological problems (Bolshakov, 2001). Internal consequences are individuality destruction. Therewith a young person social life is open to available opportunities.

Consequently, it is hard for a young person to say "I feel being myself and I feel present". In a novel "Nausea" a French existentialist Jean-Paul Sartre raises the question of a human existence essence. Objectively "a man of the crowd" is imprisoned in causal existence. "Existence everywhere, infinitely, in excess, for ever and everywhere; existence-which is limited only by existence" (Sartre, 2007).

In fact, today the modern generation plays act to itself. With infantilism it runs into "the crowd" following to social life rules. Basically, they are looking for their own selves. Besides, this self, there exists the society, which we create nowadays and which will be the basis for future generation (Kvesko et.al., 2015).

No doubt, global modernization is an essential social task. However, within these "races to the top" the human is being lost in such main aspects as the humanism towards oneself and the humanism towards the world around. A huge amount of humanistic categories is of no need. The essence, briefness and performance are more important. A sustainable illusion of making everything for future 
generation is predominant for the moment. The point is, whether the future generation will share this humanism and how much.

From our point of view, a healthy Russian society task will be the leading one in the future country development. The focus will be turned to the person with his psychological and physiological health oriented to the human value in the society.

Each person, at some point the individual development faces an important question: "Who do I am?". Means, conscious contact with itself. We don't mean school lessons of career guidance. The look is directed to the young man capable to think, reflex. In modern Russian society of a postmodern the matter and the answer to him is more difficult for reflection and understanding, than during other historical periods of our country.

Current situation brings to the fact that the modern young man, is able generation of " $Y$ " when the transferred values and vital reference points of parents don't correspond to a modern image and rate of life, or the young man isn't able to hear and understand the parent, owing to a different conceptual view on processes of socialization and communication. Thus, the modern generation of young people appears in a confusion situation. Moreover, young people test a condition of estrangement in own family, misunderstanding and complexity of acceptance of vital foundations of members of the family of the senior generations.

Different generations within one country speak different "languages". Distinctions between subjects lead to insuperable estrangement. The generation of young people is filled with tendencies of foreign countries: late marriages, phenomenon of "childfree", travel not by public transport, but private BlaBlaCar system. On the person valuable reorientation of the individual: bigger trust to private business and dispassionateness from the state, the shift of a valuable reference point to career, the changed perception of marriage and children. The domestic philosophy considers essence of national identity in researches through the concepts "self-identification", "self-determination" and "originality". At the same time including their equivalent to the concept "identity". In these researches it is necessary to mark out S. A. Bulgakov, N. A. Berdyaev, K.N. Leontyev.

The domestic philosophy considers national identity in several aspects. In one of them the question of nature of interaction with the western elements in national consciousness, about possible prospects is raised at interaction of the Russian and western cultural code. N. A. Berdyaev, S. A. Bulgakov, N. Ya. Danilevsky dealt with the matter. And other aspect is focused on a ratio with east elements in the Russian mentality. The idea reveals at K.N. Leontyev, P. Ya. Chaadayev. The possible option for understanding of national identity is an understanding of process of formation of identity of the certain individual now (Zakovorotnaya, 1999).

About what type of identity of the young man in modern Russian society of a postmodern we can speak now?

The young man with the received set of forms of cultural experience from parents isn't able to use him today in situations in life. At the same time absolutely faces other forms of people in the course of education, labor interaction, the personal relations. It develops so that the young man within one day should play perfect various roles, to be guided quickly and to change constantly under instantly replaced situations of surrounding space. 
New experience of multiple identity of generation is close to a phenomenon of "patchwork identity". This phenomenon has been introduced by the German researcher Heiner Koup for the first time. Identity is considered in the form of the project where the subject structures own fragments of experience. Within a detraditsionalization of public processes, orientation of the project is displaced towards activity of the certain subject. The project of "scrappy" identity is focused on formation of own meaning of life, also he declares search of specific abilities to establish the relations and communications. The following and an important point of the Patchwork identity project is transformation of communication processes. In the daily world of norm and the rule change with faster speed, than we manage to get used to them. Therefore the introduction question in communication and abilities to agree every time anew about rules and norms is important. The individual competence which is continuously connected with identity formation becomes necessary within the released society and focuses on formation of new communications.

\section{Conclusion}

The modern Russian society generation is a combination of sustainable and changing personalities, which is constantly straining after the crowd and still is changing to its "yesterday self" and "today self". In prospect, to start healthy future generation building it is essential to establish a life of quality position at modern youth. The life of quality term implies the orientation both to "your own self" search, and to your generation future, which allows a person to be responsible.

Thus, Heiner Koyp's ideas can act as a certain reference point for young people in modern Russian society of a postmodern. And also gives the chance to the young man to organize own vital world it is comprehended.

It should be noted that multiple identity of the modern personality takes away from unambiguous understanding and representation from own "I". And of course, answer to the question "Who Do I Am?. Invariable is a Person as the object of the world capable of a human act, sincerity and mercy.

For modern Russian youth a range of social issues complicates the direction of the life of quality vector formation. The crowd consciousness is "sleeping". A family language is strange for the youth. As a result the question How to find your place in multidimensional and fast developing modern society? appears. The answer could be found only through a young person's mental and physical activity.

\section{Acknowledgements}

Research goes within the solution of questions of social policy. Thank to National Research Tomsk State Polytechnic University and the publishing house for the opportunity to present the results of this study.

\section{References}

Bolshakov, V.Y. (2001). Evolutionary Behavior Theory. 496, 86. (in Russian)

Kachalov, N., Kornienko, A., Kvesko, R., Kornienko, A., Kvesko, S. \& Chaplinskay,a Ya. (2015). Interdisciplinary Competences and Their Status Role in the System of Higher Professional Education.

Procedia - Social and Behavioral Sciences, (206), 429-433. 
Kachalov, N., Kornienko, A., Kvesko, R., Nikitina, Yu., Kvesko, S. \& Bukharina, Z. (2015). Integrated Nature of Professional Competence. Procedia - Social and Behavioral Sciences, (206), 459-463.

Krieger, W. (2015). Soziale Arbeit im Ost-West-Vergleich. Soziale Probleme und Entwicklungen der Sozialen Arbeit in Deutschland, Russland, Armenien und Kirgisistan [PDF Version]. Retrieved from http://www.beckshop.de/fachbuch/leseprobe/9783899182385_Excerpt_001.pdf

Kvesko, R.B., Chaplinskaya, Ya.I. \& Kvesko, S.B. (2015). Labour Subtraction and Professional Burnout at Work. Eurasian Union of Scientists, (5), 79-81.

Kvesko, R.B., Chaplinskaya, Ya.I., Ishtunov, S.A. \& Kvesko, S.B. (2015). The formation of a constructive relationship to stress: methodological aspect. Fundamental and Applied Sciences V International ScientificPractical Conference Journal, (3), 154-156.

Mikhaylovskiy N.K. (1907). Heroes and Crowd, (2), 97. (in Russian)

Sartre J-P. (2007). Nausea. 178, 67.

Zakovorotnaya M.V. (1999). Person's Identity. Social and Philosophical Aspects. 182. (in Russian) 